\title{
電子部品用 $\mathrm{Pb}$ フリー $\mathrm{Zn}-\mathrm{Sn}-\mathrm{Ni}$ 合金 めっき鋼板の開発
}

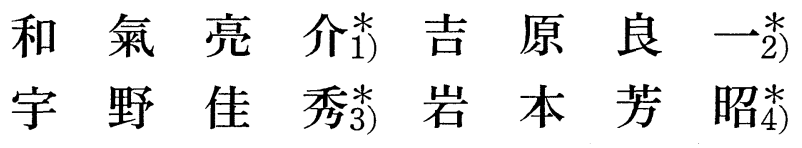

\section{1. 緒言}

近年の環境問題から鉛の有毒性が指摘され，鉛フリー化の 要請が高まりつつあり, 家電分野に拈いても, $\mathrm{Sn}-\mathrm{Pb}$ 半田 の代替として $\mathrm{Sn}-\mathrm{Ag}$ 系や $\mathrm{Sn}-\mathrm{Bi}$ 系の合金が開発され実用化 が検討されている段階である(1)(2).

電子部品用表面処理鋼板についても, 現在, 鉛-錫めっき 鋼板(ターソシート)が多用されて括り，また，部品をプレス 加工した後に $\mathrm{Sn}-\mathrm{Pb}$ 系の半田めっきが施されるケースも多 く, 鉛を含んだめっきが大部分を占めている.一部では, 電 気ぶりきも使用されているが，耐食性执よび錫の針状単結晶 ホイスカー(Whisker)の発生による短絡の問題があるため使 用部位が限定されているのが実状である.

\section{2. 開発の考え方}

著者らは，錫と他金属との合金化によって電気ぶりきの上 記二つの欠点を改善する手法として, 多層めっき後に熱拡散 を行う方法について検討した. その結果, 鋼板上に $\mathrm{Ni}, \mathrm{Sn}$, $\mathrm{Zn}$ を逐次めっきした後, 電気ぶりきラインの錫溶融装置で 加熱し, $\mathrm{Ni}, \mathrm{Sn}, \mathrm{Zn}$ の多めっき層を拡散合金化することによ って，上記した錫めっき鋼板の欠点を改善した $\mathrm{Zn}-\mathrm{Sn}-\mathrm{Ni}$. 合金めっき鋼板を開発，実用化した(3)(4).

\section{* 新日本製鐵株式會社}

技術開発本部：1)表面処理研究部部長 2)広畑技術研究部主任研究員

広畑製鐵所：3)生産技術部グループリーダー 4)錫メッキ工場課長

Development of $\mathrm{Pb}$ Free $\mathrm{Zn}-\mathrm{Sn}-\mathrm{Ni}$ Alloy Coated Steel Sheet for Electric Devices; Ryousuke Wake, Ryoichi Yoshihara, Yoshihide Uno, Yoshiaki Iwamoto(Nippon Steel Corporation) 1999年10月28日受理
表 1 に Zn-Sn-Ni 合金めっき鋼板と現行のめっき鋼板で あるぶりきとターンシートのめっき構成を示す.

$\mathrm{Zn}-\mathrm{Sn}-\mathrm{Ni}$ 合金の加熱処理は, 電気ぶりきラインの錫溶融 処理装置を用いた. 加熱後, 鋼板は直ちに水冷 (冷却水の温

表 1 各種めっき鋼板一覧.

\begin{tabular}{l|cccc}
\hline \multirow{2}{*}{} & \multicolumn{4}{|c}{ 各種めっき量 $\left(\mathrm{g} / \mathrm{m}^{2}\right)$} \\
\cline { 2 - 5 } & $\mathrm{Zn}$ & $\mathrm{Sn}$ & $\mathrm{Ni}$ & $\mathrm{Pb}$ \\
\hline $\mathrm{Zn}-\mathrm{Sn}-\mathrm{Ni}$ & $0.1 \sim 0.4$ & $4.0 \sim 5.6$ & $0.1 \sim 0.4$ & - \\
\hline \#50ぶりき & - & 5.6 & - & - \\
\hline ターンシート & - & $3 \sim 4$ & - & $36 \sim 48$ \\
\hline
\end{tabular}

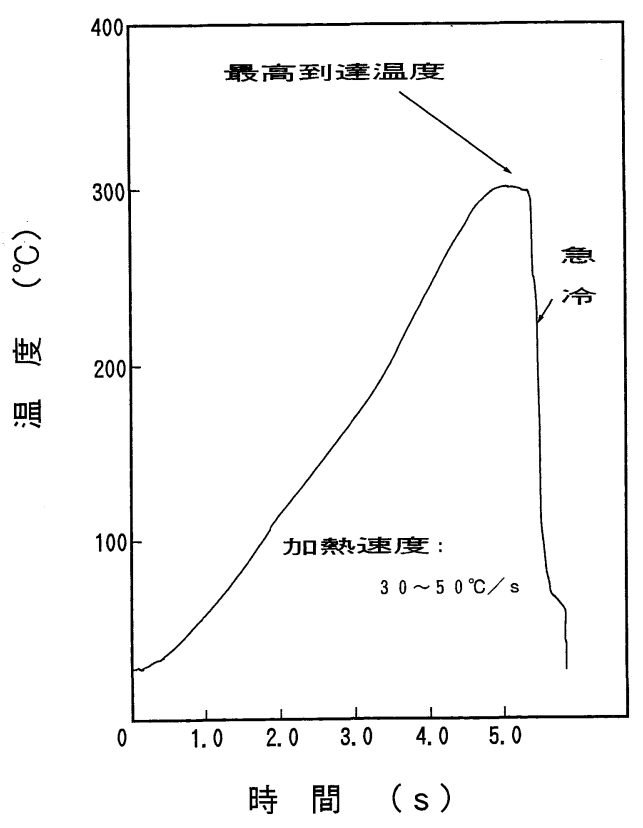

図 1 熱拡散合金化のヒートパターン例. 


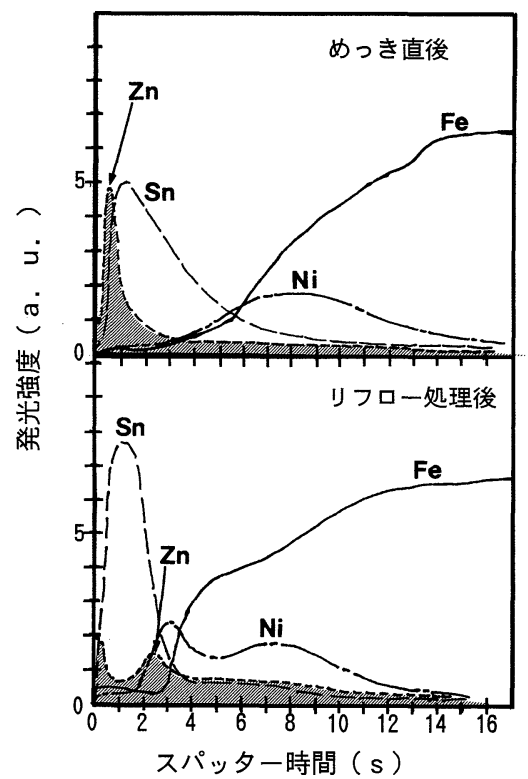

図 $2 \mathrm{Zn}-\mathrm{Sn}-\mathrm{Ni}$ 合金めっき鋼板のめっき皮膜構造 (GDS).

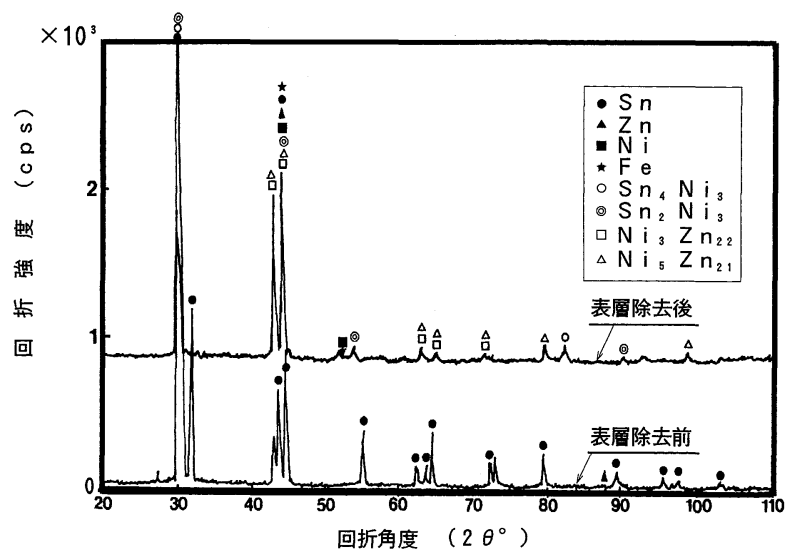

図 $3 \mathrm{Zn}-\mathrm{Sn}-\mathrm{Ni}$ 合金めっき皮膜構造 (X 線回折).

度は30 40 ${ }^{\circ} \mathrm{C}$ ) した. 図 1 に加熱パターンの一例を示した.

図 2 K, 熱拡散処理前後の $\mathrm{Zn}-\mathrm{Sn}-\mathrm{Ni}$ 合金めっき鋼板の GDS による断面方向の構造解析結果を示す. 図から明らか なように, 熱拡散処理前の状態(a)では, 表面から順番に, $\mathrm{Zn}, \mathrm{Sn}, \mathrm{Ni}$ の三層構造が認められる. 一方, 熱拡散処理後 (b)では，その構造が(a) とは大きく異なり，特にめっきの 最表層にあった $\mathrm{Zn}$ が中間層の $\mathrm{Sn}$ を通り越して，下層の $\mathrm{Ni}$ 層にまで拡散していることが分かる. また，熱拡散処理後 は, Sn の分光強度が極めて高くめっき皮膜の均一性も向上 していることが分かる。

図 3 に, $1 \mathrm{~N}$ 塩酸中で, 定電流電解を行った時, 表面電位 が途中で大きく変化する変曲点で電解剝離を中断してめっき 上層部のみを剥離したサンプルと電解剝離前の表層 $\mathrm{X}$ 線回 折結果を示す．図より，地鉄とめっき層との界面近傍には， $\mathrm{Zn}-\mathrm{Ni}$ 合金の回折ピークが顕著であり, 一部, Sn-Ni 合金
の回折も見られる.

以上の結果より， $\mathrm{Zn}-\mathrm{Sn}-\mathrm{Ni}$ 合金めっき皮膜は，上層部分 が $\mathrm{Sn}-\mathrm{Zn}$ 共晶合金，下層部が $\mathrm{Zn}-\mathrm{Ni}$ 特よび $\mathrm{Sn}-\mathrm{Ni}$ 金属間 化合物から成る構造であると推定される。

\section{3. 開発しためっき鋼板の特性}

図 4 亿，各種表面処理鋼板の塩水噴霧試験による錆発生結 果を示した。図から明らかなように, $\mathrm{Zn}-\mathrm{Sn}-\mathrm{Ni}$ 合金めっき 鋼板は，\#50ぶりきと比較して赤錆発生率は $0 \%$ 近くまで抑 制されており，耐食性の改善が顕著であることが分かる.

図 5 に現行 $\mathrm{Sn}-\mathrm{Pb}$ 半田に対する半田濡れ性拉よび半田拡 がり試験の結果を示した.

図 5 から Zn-Sn-Ni 合金メッキは，現行使用されている 材料と同等かそれ以上の半田性を有している.これは上層 $\mathrm{Sn}-\mathrm{Zn}$ 合金の融点が $198^{\circ} \mathrm{C}$ と $\mathrm{Sn}\left(232^{\circ} \mathrm{C}\right)$ 特よびターンシート (約 $300^{\circ} \mathrm{C}$ ) 飞比べ低いためであると推定される(4)(5).

また，図 6 に鉛フリー半田として検討されている代表的な 合金組成である $\mathrm{Sn}-\mathrm{Ag}$ 系合金と $\mathrm{Sn}-\mathrm{Bi}$ 系合金について半田 濡れ性を試験した結果について示す.

図のように, 使用する合金の融点 $\left(\mathrm{Sn}-\mathrm{Ag}\right.$ 系は約 $220^{\circ} \mathrm{C}$, $\mathrm{Sn}-\mathrm{Bi}$ 系は約 $\left.200^{\circ} \mathrm{C}\right)$ によてゼロクロスタイムが変化し,

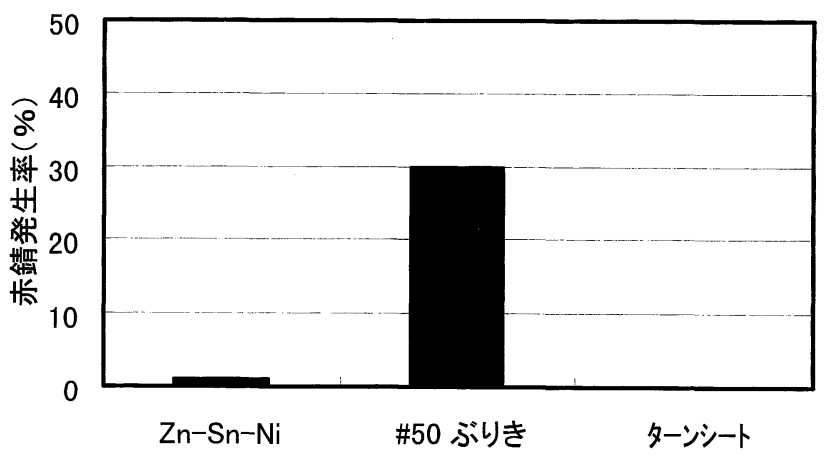

図 4 各種めっき鋼板の耐食性比較(塩水噴霧試験 72 h).

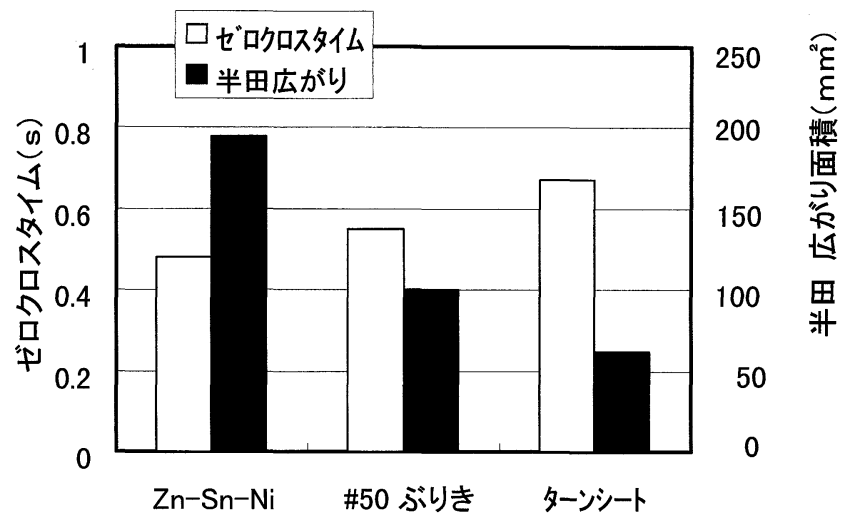

図 5 各種めっき鋼板の半田性能比較 $(\mathrm{Pb}-\mathrm{Sn}$ 半田). 


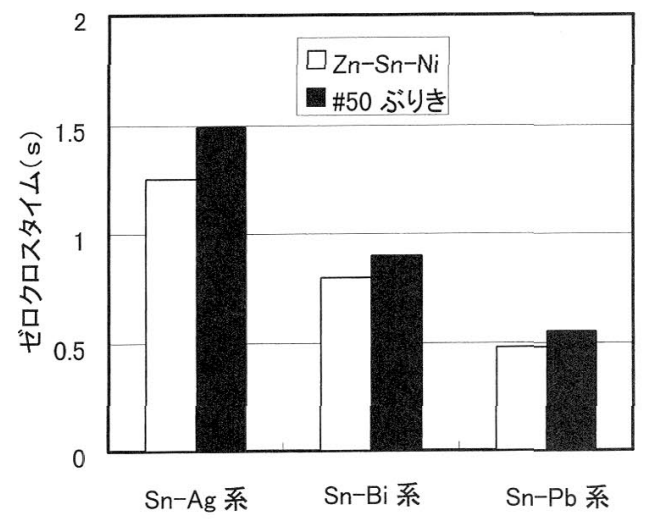

図 6 各種鉛フリー半田浴と現行半田との濡孔性比較.

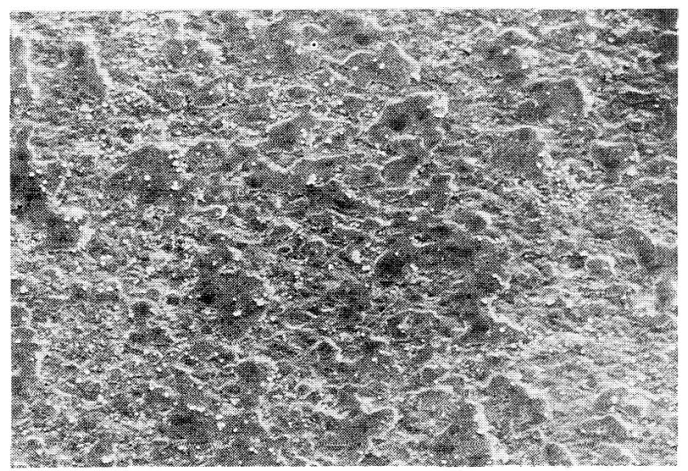

(a) Zn-Sn-Ni 合金めっき鋼板

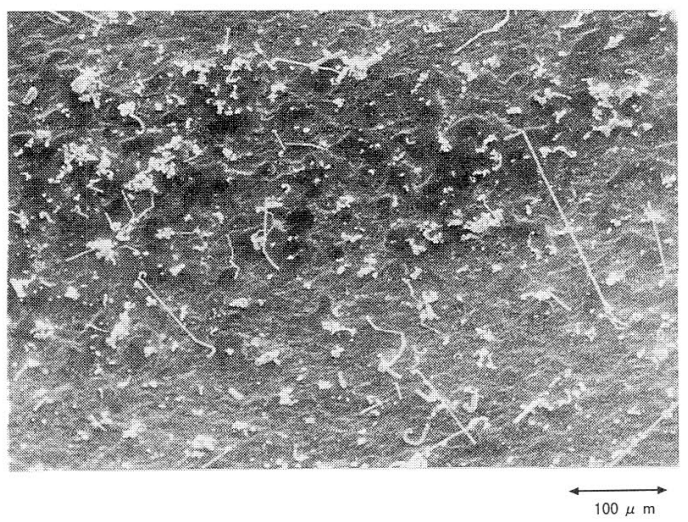

(b) \#50ぶりき

図 7 各種めっき鋼板の表面外観 (ホイスカー促進試験 後).

現行の $\mathrm{Sn}-\mathrm{Pb}\left(186^{\circ} \mathrm{C}\right)$ 半田よりも時間が長くなる傾向が見ら れるが，何れの浴に扒いても比較の\#50ぶりさより良好な濡 れ性を示して扣り問題はないものと考光られる。

電子部品材料としての重要な特性の一つに, 耐ホイスカー 性がある、特に，最近では電子部品が小型化しているため $\mathrm{Sn}$ ホイスカーが発生した場合, 回路の短絡を生ずる確率が 高くなっている. Snめっき鋼板および $\mathrm{Sn}$ を含を合金めっ き鋼板の耐ホイスカ一性については, 従来から詳しく研究さ れて持り(6)-(8), 一般的には, めっき層の厚久を厚くする,
熱処理によってめっき層中の応力を解放する，合金化する等 々の改善が提案され, また, 発生機構についても種々の検討 がなされている。図7に，ホイスカー性について評価した結 果を，比較材と共に示した。 図から明らかな上らに $\mathrm{Zn}-\mathrm{Sn}$ $\mathrm{Ni}$ 合金めっき鋼板には，電気ぶりきで見られるような，針 状のホイスカーは発生しなかった、これは一般に言われるよ らに Snが $\mathrm{Zn}$ との合金化によりホイスカー発生执よび成長 に対して必要な Sn の拡散が抑制される結果(8) と考兄られる.

\section{4. 結 言}

（1）鋼板側から Ni, Sn, 次いで Zn をこの順序でめっきし た後, 錫が溶融する温度にすで鋼板を加熱することによって 得られた熱拡散合金めっきは下層(鋼板側) 飞, $\mathrm{Zn}-\mathrm{Ni}$ 合金, 扣よび $\mathrm{Sn}-\mathrm{Ni}$ 合金から成る層とその上層には, $\mathrm{Sn}-\mathrm{Zn}$ 固溶 体を主成分とする層から成っている。

(2) $\mathrm{Zn}-\mathrm{Sn}-\mathrm{Ni}$ 合金めっさ鋼板は, 同一めっき量の錫めっ き鋼板（電気ぶりさ）に比べ，耐食性に優れる.この理由とし ては，第一に，錫中に固溶し，一部はNi と合金化した亜鉛 の犠牲防食性の寄与が，第二に，下地 Ni めっき層を付与し たことにより錫の均一被覆性が向上した結果と考光られる.

(3) 半田性に関しては, 現行のターンシートや電気ぶりき より優れた半田濡れ性, 並びに半田広がり性を有して招り, これは, $\mathrm{Zn}-\mathrm{Sn}-\mathrm{Ni}$ 合金皮膜の表層が融点の低い $\mathrm{Sn}-\mathrm{Zn}$ 共 晶となっているためと推定される。

（4）耐ホイスカー性については電気ぶりきと比較してホイ スカーの発生は全く見られずターンシートと同等の結果であ った。これは，ZnをSnに対して合金化したことによる Sn の桩散を抑制する効果と考光られる。

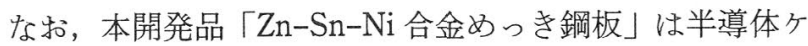
ースから電子部品のシールドケースやフレームに使用されて 扣り, 鉛フリー化のニーズに対応してその適用範囲は益々拡 大している.

\section{5. 工業 所有 権}

日本国特許第1911914号，第1931179号，第1971229号， 第1992951号, 第2010026号, 他出願 1 件.

\section{文献}

（1）菅沼克昭：回路実装学会誌，12(1997), 83.

（2）縄舟秀美：第96回表面技術協会講演大会要旨集，(1997), 260.

（3）和氣亮介ら：鉄と鋼， 77(1991), 898.

（4）吉原良一ら：新日鐵技報，No. 371(1999)，39.

(5) M. Hansen: Constitution of binary alloys, McGRAW-HILL, (1958), 1042, 1217.

（6）土肥信康：実務表面技術，27(1980)，609.

（7）川中龍介：日本洁晶成長学会, 8(1981), 145

（8）山部恵造 : 金属, 49(6) (1979), 2. 